\title{
HIP HOP AS A REFLECTION OF AMERICAN VALUES: A SEMIOTICS ANALYSIS ON SAVE THE LAST DANCE AND STEP UP MOVIES
}

\author{
Naris Eka Setyawati \\ e_naris@yahoo.com
}

\begin{abstract}
This study examines seven movies that are based on characters created by Duane Adler. They are two Save the Last Dance and five Step Up movies. This discussion is a library research which is conducted within the framework of American Studies approach under the scope of history, social, and culture. This research uses Barthes' semiotics theory on myth to analyze the depiction of American phenomena in the movies.

The objectives of this study are to examine the portrayal of Hip Hop in United States of America and to analyze the reflection of American values through movies. The discussions on the topic reveal that Hip Hop becomes the source for movies' narratives. It is manifested in hip hop related scenes of the movies. They portray signs of rebellion and juvenile delinquency in the first order-semiological system. These portrayals reflect American values of rebellion and freedom. Moreover, life struggle and American belief in the land of opportunity play the signs in Barthes' second order-semiological system. The American values reflected through the discussions are competitiveness, hard work, determined, optimism, and materialism.
\end{abstract}

Keywords: Hip Hop, hip hop, popular culture, semiotics, American values

\section{Introduction}

United States of America with its predicate of the "melting pot" society and its promising "land of opportunity" attracts immigrants to come to this land. They hope for betterment by seizing opportunity for their rights to achieve success and happiness in the middle of multiculturalism.

The immigrants have created America as it is today. They have contributed for the development of American culture. It includes African American as one of the biggest populations in America. One of African American contribution in giving color to the American culture is seen from Hip Hop.

The development of Hip Hop in America cannot be separated from the history of the country. Hip Hop was a subculture but it is already acknowledged as a culture now. It was not popular among larger society in the 1960's. However, entertainment industry sees it as a profitable product to explore.

Save the Last Dance and Step Up movies are some of profitable movies that portray Hip Hop in the narratives. Most of the movies used in this research gained financial success with box office earnings of more than \$35 million in America 
(www.imdb.com). The success of these dance movies shows audiences' interest in watching such kind of movie. Despite their interest in the dance movies, they usually take the depiction of Hip Hop for granted. In fact, the producers create a product which reflects the society and introduce values (Nachbar, 1992, p. 6). There is an interwoven relation of popular culture product and the society.

Regarding the explanation, this research writer sees the relation of Hip Hop in American society and hip hop as product of popular culture. This relation leads to awareness toward the portrayal of Hip Hop in American dance movies. This study is done to highlight social issues through American popular movies. To be more specific, it is to examine the depiction of Hip Hop in United States of America to reveal the reflection of American values.

\section{Hip Hop in the United States of America}

Unaware of the fact that Hip Hop is a culture, some people take the term "hip hop" and other related terms to it for granted. However, this research distinguishes some terms related to the culture and the product of popular culture. The people who are related to Hip Hop as a culture will be called as hiphoppa. Hip Hop elements are emceein-the utterance in music area, deejayin-the act of manipulating sound, graffiti art-the art of symbol writing, and breakin-the dance. Whereas hip hop, hip hopper, rap, DJ, graffiti and break dance are used to mention something related to the products of popular culture.

Hip Hop early existence has a close relation to American marginalized societies. Neglected in the ghetto, minorities in the South Bronx area developed breakin, emceein, deejayin, and graffiti art. They grew stronger as block parties were popular in the 1960s and 1970s.

The block parties' phenomena created four basic elements that marked the existence of Hip Hop - coined by Lovebug Starski and Afrika Bambaataa popularizes it (www.zulunation. com). The parties that were held by blocking the street were mostly held by DJ Kool Herc, Grandmaster Flash, and Afrika Bambaataa. They are some Hip Hop pioneers who are mostly former gang members (Watkins, 2005, p. 22). However, these pioneers used block parties to change the negative thing to a positive one (Watkins, 2005, p. 23).

Block parties were not just a place where youngsters performed creativities. The parties along with Hip Hop were used as ways to "channel the anger of young people in the South Bronx away from gang fighting" (Lipsitz, 1994, p. x). It is hoped that African and Latino descent could get away from the negativity - gang violence, drug abuse, self hate, violence - that was plaguing our streets (Bambaataa, www.zulunation.com). The main goal of Hip Hop was to keep the youngsters away from the gang life and change the Bronx neighborhood to be more positive one.

The positive purpose shows Hip Hop flexibility to adjust itself to the development of American society. This ability causes its elements to gradually improve. Motley and Henderson (2008) stated that, "the elements "can be combined by limitless factors to create culture and community" (p. 246). Knowledge holds emceein, graffiti art, 
deejayin, and breakin together (Bambaataa: www.zulunation. com).

Hip Hop's creative contributions in music, dance, art, poetry, and fashion has influenced entertainment world within the past 20 years (Bambaataa, www. zulunation.com). It makes Hip Hop to be more popular and change it from subculture to culture. Brent D. Glass, director of the National Museum of American History, believes that "hip-hop - the music, dance, and art-is now an important part of American culture."1

The struggle to be called as a culture can be traced back through the development of Hip Hop's popularity. It was first popularized by the works of emcees and deejays that flourished through radio. The success of Hip Hop on the radio made music industry try to extend its profitable business through visual media. In the 1980s, MTV telecasted black music video and gained huge popularity of American society. Richardson (2002) believed that this phenomenon "is widely viewed as a turning point in hip-hop and rap music video access to mainstream media" ( $p$. 183).

The success of black music video in 1980 led Hip Hop to become hip hop, emceein to rap, deejayin to DJ, graffiti art to graffiti, and breakin to break dance. The online media that the Zulu Nation has managed strengthen it by saying "from the 80 's on, the Rap industry and media have helped to make the terms "Hip Hop" and "Rap" synonymous, leaving out the other elements included in the culture".

1 Retrieved from http://americanhistory.si.edu/
Music industry shifted Hip Hop as culture to hip hop or rap. It applied a business model that only promoted the most commercial one. The most marketable themes of hip hop are dominated by violent, rebellious and highly sexual content (Adaso, 2007, p. 6). Music video exposes pictures of sexuality, luxurious life, alcoholic consumption, gang fighting, and drug dealing.

Hip Hop through hip hop transforms its focus from creativity to marketable industry. It made Hip Hop to be connected to negative image and became "underrepresented in mass media as the commodities of gangster, ghetto, violence, drug dealer, and misogyny" (Hart, 2009, p. 10). Regardless to the phenomena, hip hop became one of the economic staples of the music industry in 1990s (Cruz, 1999, p. 888). Entertainment industry takes any chances for the sake of profit. The profit does not only come from music videos but also from the extension of the business to movie on television and in cinema.

Hip Hop through audio visual media has come to the stage of popular culture since it is "...widely shared among the population" (Mukerji and Schudson, 1991, p. 3). As Storey stated that, "[its] widely favored or well liked by many people" (as cited in Edensor, 2002, p. 14) make the industry to produce hip hop related movies until the new millennium. Among the popular movies during 2001 to 2014, there are several popular dance movies which based on characters created by Duane Adler. Their popularity can be seen from the series of the movies started from Save the Last Dance (2001), Save the Last Dance (2006), Step Up (2006), Step Up: the Streets (2008), Step Up $3 D$ (2010), Step Up: Revolution (2012), and Step Up: 
All In (2014). Thus, most of them gained financial success with box-office earnings of more than $\$ 35$ million the United States alone (www.imdb. com).

The movies which based on characters created by Duane Adler are chosen as the objects of this study. The writer sees possibility of these popular culture's products in giving point of view toward American society and culture that reflects American values. These movies do not only produce profitable amount of money for the makers but also provide sources for this research writer.

\section{Hip Hop as Signifier of American Liberty}

In some studies, the term liberty and freedom are used interchangeably. However, this study distinguishes them based on the relationship of three charters of freedom. Those three documents are the United States' Declaration of Independence, Constitution, and Bill of Rights. The correlation between the three American documents shows that liberty covers freedom. Through liberty, Americans can exercise freedom. The freedom includes freedom of expression that covers freedom of speech (Paul, 2011).

In practicing freedom, good character of the society is needed. Responsibility toward the practice of freedom is important otherwise it can result to disorder and chaos (Paul, 2011). These problems can happen since the practice of freedom can turn to whether positive or negative.
In the sphere of American society, the phenomenon of Hip Hop is also seen from positive and negative perceptions. Some see it as the practice of freedom that gives positive effect to the society. Others think that it closely relates to bad things. The depiction of Hip Hop in the Save the Last Dance and Step Up movies can explore these two perspectives in the society. This phenomenon can be seen in these artifacts since movies may reflect the society and introduce values (Nachbar, 1992, p. 6).

Considering the depiction of Hip Hop in movies, negativity is more related to it. It happens because mainstream media exposes more to it (Hart, 2009: 10). The exposure is more to violent and rebellious as they are the most marketable themes (Adaso, 2007: 6). Regarding these phenomena, the hip hop theme that is portrayed in Save the Last Dance and Step $U p$ movies follows the view of the marketable aspects. The violent, rebellious behavior and glorifying gangster life are portrayed in the movies (Adaso, 2007, p. 6).

The first Save the Last Dance portrays the phenomena of gang life through the depiction of Malakai. He gets involve on drug dealing, gun owning, and gang fighting (the Last Dance, 2001: 00:45:2045:54; 01:33:40-36:57). Similar portrayal on gang life can be seen through PJ in Step $U p$. It portrays in the scene when PJ shot Skinny because he stole PJ's car (Step Up, 2006: 01:23:10-01:26:29). These things confront law and are regarded as "wrong." They are usually done by youngsters and are called as juvenile delinquencyrepresents behavior that run counter to law and opposed to those of the dominant social order (Matza, 1999: 712). 
The narratives of breaking the law also can be seen in Step Up: The Streets. It reveals vandalism-includes breaking, destroying public facilities, and painting graffiti on a property that does not belong to the artist (by National Crime Prevention Council, p. 2). All of those vandalism are portrayed when 410 Crew broke, destroyed, and write graffiti on MSA's dance studio (Step Up: The Streets, 2008, 01:04:00-01:05:08). The rebellious vein inherent in Hip Hop culture (Forman and Neal, 2004, p. 342) also can be seen when 410 vandalizes a subway train and a station (Step Up: The Streets, 2008: 00:00:41-03:56).

Rebellious action is not only connected to violating law but also in the form of violating moral value in the society. It can be seen in Save the Last Dance through Chenille. She is described to be a student who has already had a baby. This condition surprises Sara, a white girl who has just moved in to ghetto (Save the Last Dance, 2001, 00:25:10). This discrepancy of point of view toward unwed mother shows that the portrayal in the movie indicates violation of moral value of larger society.

Another form of rebellious is portrayed through the depiction of breaking the rule. The portrayal can be seen from the narrative of the second Save the Last Dance. It happens when Mrs. Delacroix warns Marcus because of his inappropriate clothing in ballet rehearsal (Save the Last Dance, 2001, 00:11:23-00:11:45). The characteristics of being obedience and rebellion is measured from how someone behaves toward the way he dresses up.

Simmel explained the situation of rebellion by saying that, "clothes can serve as triggers". It triggers identification of an individual based on how they look since fashion symbolizes the self as the cultural extension of oneself (as cited in Baxter and Marina, 2008, p. 105). It implies that an individual's characteristic can be determined based on his appearance and his attitude toward the appearance.

Dance as a strong element of Hip Hop can also be another aspect that is considered to represent rebellion. This view can be traced back to the time when breakin was still a street form that, in the eyes of the authorities, too closely resembled stylized gang fighting (Perkins, 1996, p. 60). This gang fighting thing resembles rebellious behavior.

The phenomenon of rebellion that is seen through dance is portrayed in Save the Last Dance. It tells about Sara, a ballerina, who secretly choreographs for hip hop beat (Save the Last Dance, 2006, 00:53:4100:54:29). Other portrayal is seen in Tyler's rehearsal scene when he calls ballet as boring and stiff (Step Up: The Street, 2006, 00:32:10-00:32:28). Similar portrayal on unexciting ballet movement can be seen in Chase's narration on the MSA audition scene (Step Up: The Street, 2008, 00:16:09-00:16:20). Thus, Emily mentions her ballet movement "kinda boring" (Step Up: Revolution, 2012, 00:21:25). Ballet movement feels stiff and boring for hiphoppers since the dance in hip hop involves a quick wit on a physical level (Huntington, 2007, p. 40). Break dance requires quick thinking and action toward the beat and toward other opponents' movement especially in dance battle.

The discussion shows actions and expressions of youngsters in the movies that expose rebellion. This rebellious 
behavior is achieved through the depiction of hip hop related scenes regardless to the knowledge beyond the portrayals. The rebellion plays the role of sign in Barthes' language meaning. Concerning historical knowledge on social and cultural, another level of understanding meaning can be achieved (Barthes, 1991, p. 116, EdgarHunt, et al, 2010, p. 70, and Stam, et al, 1992, p. 225). It happens because experiences in the American history can be the starting point to understand the phenomena in movies (Adi, 2003, p. 242).

It is known that Hip Hop was born in the late sixties. It was the time when Americans challenge many traditions as the legacy of counterculture. Anderson states that juvenile problems such as delinquency, crime, violence, and unwed mothers are more likely to be seen in this era rather than in the previous generation. It can be seen that youngsters of this era, especially seen in ghetto, began to express their own values. It is seen as cultural rebel by elder generation (Anderson, 2012, pp. 50-185). However, the cultural rebel fought for something more than violation to the old value. They tried to liberate themselves from the domination of the majority.

The groups who fought for rights were the minorities such as African and Mexican American (Hirschman, 1983, p. 416). It happens because they were put aside by the dominant. They "were not considered to be fitted to the melting process" of the melting pot (Abrahams, 1971, p. 119). The peak of this discontentment happened in the sixties when the minorities rebelled to be free from the domination. Civil rights movement marks this demand. Through this movement, the minorities wanted to change the assimilation to be integration. This is the time when those people become the agent of social revolution and mark the existence of multiculturalism (Anderson, 2012, p. 192, Owen, 2005, p. 2). One of the products of what multiculturalism achieved is Hip Hop. It is "the future of language and culture in the multicultural society" (Hoch, 1993, p. xvii).

The explanation on American experience in the sixties shows that Americans faced social challenges. One of them is the problem of being a single parent in a teenage year. The understanding on unwed mother portrayed in the first Save the Last Dance is seen as the result of historical event in the sixties. Chenille's portrayal of rebellion is part of practices freedom from an old value. It shows an attempt to liberate from older generation's sexual mores that glorify Puritan values (Anderson, 2012, p. 122). It reveals social condition in the society that youngster was no longer wanted to be bond to the value of preserving sexual intercourse for marriage.

The freedom that teenager believed to be liberation, is part of the rejection on the idea of society's assimilation. It reveals the failure to preserve the dominant's place in the melting pot image. Thus, it helps to see multiculturalism in American society. Process to gain freedom in the multicultural society is reflected in rebellion.

There are some more rebellious behaviors in the movies that can be discussed. The first Save the Last Dance portrays juvenile delinquency through Malakai, the first Step Up movie through PJ, and the Step Up: The Streets through 410 Crew. The 
portrayal in the movies leads to grasp rebellion image. It happens because they are obviously displayed in the movies as actions that breaking the rules and laws. However, these depictions give opportunity to grasp another meaning regarding the social condition in the sixties.

The sixties was the time when American society faced social revolution. It was a result of minorities in questioning the melting pot image. African American as one of minorities group other than Mexican American was the prominent one who fought for their rights. The dominant society regarded their attempt as rebellion. However, the younger generations regarded this effort to achieve social change.

The social change in the sixties is the result of discontentment of those minorities who were neglected and isolated to the ghetto. They were not considered to be able to blend in to the advancement of their life. They were forced to live in the place where economic growth was hard to achieve. Furthermore, self expression was trifle thing to be respected. Accordingly, it was a place where hostility most likely to happen.

The way of life in ghetto shows an effort to be liberated from economic condition that was suppressed by the dominant. Youngsters started to create groups known as gang that gave them access to gain income. The gang division created conflict of territory to earn a living. It then led the gangs to defend on their possession by marking their territory with their artistic expression.
There is no surprise that the gang members who got involve to the gang activities did an action that violated rules and laws. Fighting among gang members were common thing to happen in ghetto (Watkins, 2005, p. 22). It did not only involve physical contact but also involved shooting. It makes sense that those people owned guns whether to attack others or even to protect themselves.

The historical background reveals an attempt to gain freedom from dominant's limitation. The portrayals of breaking the laws as glorifying gangster life through Malakai and PJ demonstrate the only option that was provided. The gangster life became an effort to be free from economic boundary. It happens as they are minorities who have no access to the economic assimilation.

Vandalism illustrates through 410 Crew is seen as liberation reaction toward inadequacy on public facilities' access. This phenomenon is part of the unequal distribution of assimilation for minority because socioeconomically advancement was limited. Vandalism is also part of minorities' effort to defend what they have. 410 Crew assumes that The Streets belongs to ghetto society. They wanted to preserve their freedom of expression through artistic expression in The Streets Competition.

The artistic expression includes fashion. It is portrayed through Marcus in the second Save the Last Dance. However, this artistic expression is portrayed through clothing conflict. Marcus is labeled by his lecturer as a rebel because he wears trousers that are inappropriate in ballet rehearsal. His being rebel is determined based on his appearance since fashion symbolizes the 
self as the cultural extension of oneself (Simmel as cited in Baxter and Marina, 2008, p. 105).

The different culture that enables someone to be identified in the multicultural society is blocked by the view on rebellion. This perspective prevents the artistic expression to be seen. The aspect of minority does not fit to the melting pot emphasizes in this point of view. Thus, freedom of expression that youngster does cannot be obviously seen.

The rule that makes people see rebellion on fashion also applies to other form of artistic expression, dance. Some of the portrayals of rebellion on dance reveal youngsters' rejection on the stiff and boring movement of ballet (Step Up, 00:32:15, Step Up: The Streets 00:16:09, Step Up: Revolution 00:21:25). Those youngsters try to modify ballet movement to a more danceable tune. A stronger attempt to alter the movement can be seen in the second Save the Last Dance. This movie describes a ballerina who does not only modify ballet movement but also choreographs for hip hop music. These depictions are seen as youngsters' attempts of shifting the movement from the existing rule.

Youngsters' effort to modify and adjust dance movement to danceable beat was considered as rebellion. The rebellious image is embedded in the break dance since its early existence. Perkins (1996) stated that break dance "in the eyes of the authorities, too closely resembled stylized gang fighting (p. 60)." Furthermore, the emergence of music also influence dance's image. Music was used as a way to depict social condition by the minority. In the sixties, "some rebels created music to deliver their values and views (Anderson, 2012, p. 117)." It can be seen that music was created to deliver message. In contrast to rebellion image, this statement gives different point of view toward what youngsters do.

A more danceable music influenced youngsters in the ghetto to expand their ability in dancing. They increase their capacity to synchronize movement with the beat. They have freedom toward themselves through this process. It can be seen that they are practicing their right to perform their talent as expression of freedom of speech. This right makes those youngsters to be liberated from limitation to their movement. It gives them chance to be free from the rigidity and getting away from the boundary of their talent. However, their voice cannot be well delivered as they perform it to the existing formal rules of movement.

Similar portrayal on the dance as rebellion is depicted in Step Up: The Streets, Step Up 3D, and Step: Up Revolution. These three movies describe youngsters' who perform their dance in public facilities such as in a park, streets, subway train, and even in an event. Their performances are considered to be disturbance for the society. However, this phenomenon happens for a reason. The history behind it can explain the reason why.

Looking back to when subculture began, artistic expression was used as a way for youngsters to be recognized. They want to be acknowledged by larger society, yet there was no facility to support their capacity. As a consequence, subculture like Hip Hop was born on the street through 
block party. It is a place where youngsters can express their creativity through dance and music. Moreover, graffiti art was expressed on the train so that people could see their existence. Yet, it was also used by gang members to mark their territory (Price, 2006, p. 28). These phenomena on Hip Hop are depicted in movies in a more rebellious way rather than the artistic expression of practicing freedom.

This discussion reveals that rebellion and juvenile delinquency in the language meaning is a starting point to achieve deeper meaning. Knowledge beyond the representation enables to see the reflection of the phenomenon. Hip Hop phenomenon that can be seen in the movies provides two meanings of Barthes' myth theory as the following table:

\begin{tabular}{|c|c|c|c|}
\hline $\begin{array}{l}\text { Signifier } \\
\text { hip hop }\end{array}$ & $\begin{array}{l}\quad \text { Signified } \\
\text { rebellion and juvenile } \\
\text { delinquency }\end{array}$ & & \multirow{3}{*}{$\begin{array}{l}\text { first order- } \\
\text { semiological } \\
\text { system } \\
\text { (language } \\
\text { meaning) } \\
\\
\text { second order- } \\
\text { semiological } \\
\text { system (myth } \\
\text { meaning) }\end{array}$} \\
\hline & $\begin{array}{c}\begin{array}{c}\text { Sign } \\
\text { hip hop }\end{array} \\
\text { Signifier }\end{array}$ & $\begin{array}{l}\text { melting pot } \\
\text { multiculturalism } \\
\text { freedom } \\
\text { Signified }\end{array}$ & \\
\hline \multicolumn{3}{|c|}{$\begin{array}{c}\text { hip hop } \\
\text { Sign }\end{array}$} & \\
\hline
\end{tabular}

It tells that rebellion and juvenile delinquency as a sign in the language meaning has become signifier in the myth meaning regardless knowledge beyond the portrayal. The meanings in the second part are achieved through understanding on melting pot, multiculturalism and freedom in American society as the signified.

\section{Hip Hop as Signifier of American Life}

One of the most essential driving forces for the advancement of Americans is their belief in "American Dream." It was coined by James Truslow Adams in his book The Epic of America in 1931. He says that it is "that dream of a land in which life should be better and richer and fuller for everyone, with opportunity for each according to ability or achievement (as cited in Abid, 2012, p. 1)." It implies that America is a place where people have chance to have a better, richer, and fuller life based on their effort to achieve it.

The seed of the "American Dream" has existed long before Adams coined the term. The foundation for the idea is the Declaration of Independence as this document covers fundamental Americans' rights (Abid, 2012, p. 1). The rights give the society chance to pursue their dream. This pursuing dream is associated with the pursuit of happiness in the Constitution.

Some people say that the pursuit of happiness is a feeling of satisfaction (Graaf and Musikanski, 2011, p. 56; Murray, 1991 , p. 240). Some others relate it to financial success. Happiness for some people includes having money, being wealthy, and famous (Abid, 2012, p. 4; Muniroh, 2009, p. 33; Murray, 1991, p. 241; Putranto, 2012). The existence of emotional and material happiness can be traced back to the early American settlers who came to the new world with a hope of a better life. Muhni (2010) categorized the pursuit into religious hope and the secular dream (p. 106).

The religious hope is especially practiced by the first settlers whose aim was to acquire freedom to embrace any religion and belief. However, they also believe in the opportunity "to advance economically if one was willing to take the risk to go to the "New World" (Weaver, 1999, p. 4)." It shows that the material goal also became one of their purposes. It gives influence to Americans to achieve the dream of being 
wealthy and being freed from poverty (Muhni, 2010, pp. 106-109).

The two categories mentioned above are goals in achieving the American Dream. Muhni says that "the Americans have a dream in pursuing happiness which is often called the American Dream (Muhni, 2010, p. 106)." It suggests that the American Dream covers the act of Americans in pursuing happiness. The happiness is "the last goal of the American Dream and the real American Dream is the Pursuit of Happiness (Muniroh, 2009, p. 33)."

The meaning of American Dream transforms from time to time. Some say that it is now depends on each individual concept. However, this recent time, Americans tend to practice the secular dream. It can be seen from the goal that they want to achieve. They stuck in the quest of the materialistic ends (Albee as cited in Abid, 2012, p. 5). The American Dream that Americans practice is now focusing on acquiring materials. The core of American Dream emphasizes on property and economic (Kurian, 2001, p. 98).

The practice of focusing on earning materials is based on the success stories that Americans have achieved known as the rags-to-riches. It becomes the fundamental materialist version of the American Dream (Lemay as cited in Ulinnuha, 2005, p. 37). The story makes Americans to believe that America can change them from having nothing to have everything. However, it can happen under a condition. Muhni (2010) said that happiness requires equality in rights (p. 107). Muniroh (2009) agreed with this statement by saying that "both opportunity and success can be gained by all without looking at the status, gender or race" ( $p$. 33). There is equal chance for everyone to get opportunity and to become successful.

The opportunity will be wasted when Americans do not have quality to seize it. There is a chance for everyone to be successful as long as "they were willing to learn and endure hardship" (Ulinnuha, 2005, p. 66). Moreover, they realize that opportunity exist not only for an individual but also others. It forces them to compete on it. Thus, hard work is required and it requires competitive individual (Potter as cited in Muniroh, 2009, p. 35).

The quality to be competitive is needed as American competition to seize the opportunity is intense. It especially happens when Americans try to reach the financial success, material comfort and dream of fame (Putranto, 2012). The struggle on the competition has become more complex because opportunity exists not only for an individual but also others. It forces American to compete on the opportunity and be aware of their ability as well as others'. Both individual and collective have to be ready to learn and endure hardship (Ulinnuha, 2005, p. 66). The portrayals on the effort are depicted in Save the Last Dance and Step Up movies.

The depiction of someone in this case a dancer's effort who wants to step level up can be seen in audition. In the scope of dancers' life, an audition can be mentally, physically, and emotionally tiring (Schupp, 2015, p. 157). The dancers have to perform what they have got in order to fulfill the requirements to pass an audition. It requires hard work since the participants 
have to compete with other talented dancers. They have to struggle to show their capacity to be admitted. The dancers' struggle in audition is portrayed in the first Save the Last Dance movie.

A dancer's struggle is seen from Sara who struggles to get into Juilliard. Her failure in the first attempt and her mother's death during the audition brought her down. Nevertheless Derek, a hiphopper from Baltimore ghetto, raises her spirit up (Save the Last Dance, 2006, 00:56:00-00:58:27). He helps Sara to be able to perform the free form dance for the second audition in the same school.

Another portrayal of determination for an audition can be seen in Tyler, a hiphopper from Baltimore ghetto, of the first Step Up. His decision to be a transferred student in Maryland School of the Art makes him realize that he has to work hard for the chance. He even tries to dance ballet in the middle of his community service after his school time.

A hard attempt to succeed in audition is also depicted in Step Up: Revolution through Emily who wants to be an apprentice in a contemporary dance company. Her struggle leads her to join a break dance crew and gets away from her comfort zone to broaden her interpretation on dance.

A struggle in life also depicted in the Step Up: All In. The portrayal of Sean shows the struggle for audition by gathering people to form a new crew (Step Up: All In, 2014: 00:17:54-00-32:51). He has to create his own crew because his friends have left him. It happens because they have financial problem to support their life in the new environment. Dancers' life is hard for them. Being selected to support a famous company for campaign even does not help them in the dance career. After they have finished their contract with the company, they have to join auditions in order to earn money. They have to compete with a lot of other talented dancers in order to get a job.

Presenting ability for dancers is also can be done in the form of showcase. Showcase requires hard work in order to perfectly execute the performance to amuse the audiences. One of the movies that present the struggle in preparing a perfect showcase is the second Save the Last Dance. It is seen when Sara, a prima ballerina, choreographs for both of Miles' hip hop performances (Save The Las Dance, 2006, 00:53:45, 01:24: 17). She has to manage two hip hop projects in the middle of her rehearsal for Giselle concert. Besides, she has to keep her choreographing for hip hop beat secret from her ballet lecturer.

Being determined to work hard on a showcase is also portrayed in the Step Up: Revolution. It is depicted through The Mob Crew's dance performance to protest the project of Anderson's company. They want to fight for their community so that the company will not destroy their neighborhood to build hotel and shopping mall. This crew's showcase is done three times before the company wants to hear their voice.

The struggle to be recognized is also done through Competition. It is a place for dancers to compete to be acknowledged, to be the best, and to win prize. They have to put a great effort as the competition is 
harder especially when there is a great amount of money to win. The movies that portray this phenomenon are the third to the fifth Step Up movies.

The Pirates Crew needs to win The World Jam Competition to save their house in Step $U p 3 D$. In the process of winning the competition, The Pirates' leader has to face his best friend and was asked to quit the competition. However, he refuses it and keeps on leading the crew in the dance battle to win the 100.000 dollar. The motive in solving financial problem also can be seen in the Step Up Revolution.

In the forth Step Up, The Mob Crew joins YouTube video contest to win a hundred thousand dollar grand prizes to support their life as dancers. Their struggle includes attempt of dancing that risk them to be jailed. They also face obstacle from a business company that wants to reconstruct their neighborhood. They realize that winning money cannot save their environment. They finally sacrifice their ego on winning money and turn to protect their neighborhood.

An attempt for betterment is also presented in the sixth Step Up movie. It exposes the effort of LMNTRIX Crew to win money as well as three years contract in Las Vegas. The members of this crew have the courage to leave their job for the competition. They dare to take the risk that makes them work hard to show their capacity. All of their energy is focused on the competition.

When winning money becomes the main purpose in the discussion, Step Up: The Street portray different purpose. It can be seen on the struggle of The MSA Crew in
The Streets Competition (Step Up: The Streets, 2008, 01:22:20-01:30:20). This crew has to face humiliation from 410 Crew because they were considered to be outsiders who learn break dance from school. It leads them to practice harder to prove that they have capacity and get the title to be the best crew in the neighborhood. They do it because the main purpose of the competition is to gain respect.

As can be seen in the discussion, movies' scene in the form of audition, showcase, and competition becomes the life struggle that dancers have to face. However, these performances reflect more than their portrayals. It requires knowledge beyond the portrayals that enables to understand Barthes' myth meaning (Barthes, 1991, p. 116; Edgar-Hunt, et al, 2010, p. 70; Stam, et al, 1992, p. 225). There is a relation of history to the life struggle that is portrayed in the movies. There is something more than enduring hardship in life.

Further exploration beyond the perspective is needed to reveal the myth meaning since Hip Hop inspires filmmakers to adopt 'street' signifiers (Saunders as cited in Blanchard, 1999). Hip Hop plays as a source for movie makers to adapt Hip Hop related aspects to the movies. The depictions of performances portrayed in the movies have their distinctive characteristics that distinguish them from one another. Audition is an opportunity to demonstrate abilities in an audition (Schupp, 2015, p. 157). It is a media for those who want to show their capability to be admitted by judges or juries.

The audition is portrayed in some of movies' scenes such as in the first Save the 
Last Dance, Step Up, Step Up: Revolution, and Step Up: All In. All of those movies show opportunities for dancer to achieve what they have been dreaming of. Adams stated that the opportunities show the promise that America can give for its citizens (as cited in Abid, 2012, p. 1). Additionally, Americans believe in the equality as "...all men are created equal..." strengthen their willing to pursue happiness.

The movies that portray auditions show dancers' hard work in pursuing their dreams. In the first Save the Last Dance, Sara's dream leads her to join an audition to get into Juilliard dance school. Tyler in the first Step $U p$ movie tries to achieve betterment through audition to become a transfer student to MSA. Emily in Step $U p$ : Revolution pursues her dream through audition to be an apprentice for a dance company. Thus, The LMNTRIX in Step Up: All In joins an audition to be able to be admitted in The Vortex Competition.

All of the dancers see that there are opportunities for them. They have equal chance to join auditions and become successful in their attempt. It can possibly happen if they try hard to achieve their goal as Americans value success from hard work (Putranto, 2012). These phenomena are seen through the abilities of the characters in the movies to achieve their goals to be admitted in the auditions.

Showcase is another form of performance that gives choreographers the opportunity to present their work (Valle, 2014, p. 1). It can be seen in the second Save the Last Dance that shows Sara choreographs for Miles performances. Her ability in choreographing is approved by Miles' trust on her choreograph, lecturer's compliment on her piece, and the contract that Miles gets from her choreography. Sara's determination to manage all of the obstacles makes her succeed to pursue her dream.

Portrayal on opportunity to present dancers' work also can be seen in the Step Up: Revolution. Through showcases, The Mob has chance to show that the neighborhood has a lot of potential individual. Their eagerness to show their capacity shows equality for them to achieve betterment especially for the environment. It can be seen from their accomplishment to stop the project that endangers their neighborhood. Furthermore, the dancers' courage makes them to be acknowledged by getting contract for a job. Thus, they do not only save their environment but also achieve happiness.

The other kind of performance is competition. It has become the spirit that characterizes Americans (Montagu, 1967, p. 106). It is driven by the belief in competition to be an opportunity to succeed not opportunity to fail (Huber, 2013, p. 53). Those who determine to pursue happiness have a chance to achieve it. Effort to achieve happiness has to be done since American values success from hard work (Putranto, 2012).

The attempts in competition have already described in earlier discussion. They are presented in the movies with the aim to win money. The secular dream in achieving happiness through financial comfort is presented in the movies' scenes. Movies such as Step Up: 3D, Step Up: 
Revolution, and Step Up: All In portray this phenomenon.

Both of the third and forth Step Up depict dance crews' attempt to win 100.000 dollar from competitions. However the sources of opportunity in those movies are different. Step Up: $3 D$ 's opportunity comes from The World Jam Competition. This kind of competition can be understood through the existence of world break dance competition.

Regarding the competition, the depiction in the movie resembles to world break dance competition especially the World Hip Hop Dance Competition. This competition is started in 2002 and based in Los Angeles (www.hiphop international.com). It requires dance crews to battle in the contest to win sum amount of money. This phenomenon is portrayed in the Step Up: $3 D$ to create the depiction of an opportunity. The Pirates whose members have put great effort successfully seize the chance to win the grand prize in the competition.

The opportunity in Step Up: Revolution comes from viral video contest. This kind of contest can be found in the internet from various sources with different categories and grand prizes. This viral video contest is depicted in the movie as viral video contest on YouTube. Even though The Mob dance crew in the movie does not win the grand prize, they successfully get a job contract.

The competition to win a contract in Las Vegas is described in Step Up: All In. It shows another source of opportunity to achieve a dream. It is seen as a grand dream for dancers to be able to have their own stage in entertainment industry. The phenomena of being able to get contract in Vegas can be traced back through the Jabbawockeez achievement.

The Jabbawockeez is the winner of America's Best Dance Crew the first season in 2008. Their success in the competition leads them to be able to debut on their own stage in Las Vegas in 2010 (http://www.jbwkz.com/). This dance crew has their own show PRiSM at Luxor Las Vegas in 2013 (http://www.luxor.com/ entertainment). Thus, this phenomenon of the existence of opportunity in American society is portrayed in the movie. It shows the success of dance crew in their pursuit of happiness as The LMNTRIX wins the competition.

Regarding the discussion, it can be said that Save the Last Dance and Step Up movies depict hip hop related scenes through performances. They are audition, showcase, and competition that are depicted as life struggle in dancers' life since they have to work hard in facing the performances. However, the hard work is not seen as burden in life in the second order-semiological meaning. It becomes the process in their attempt to achieve their dreams. It is a risk that Americans have to face in pursuing happiness. This perspective is achieved regarding the belief in America as the land of opportunity and the existence of equality to seize the chance. According to Barthes' myth theory, it can be summed up as follow: 


\begin{tabular}{|c|c|c|}
\hline $\begin{array}{l}\text { Signifier } \\
\text { hip hop }\end{array}$ & \begin{tabular}{l}
\multicolumn{1}{c}{ Signified } \\
rebellion and juvenile \\
delinquency
\end{tabular} & \\
\hline & $\begin{array}{c}\begin{array}{r}\text { Sign } \\
\text { hip hop }\end{array} \\
\text { Signifier }\end{array}$ & $\begin{array}{l}\text { melting pot } \\
\text { multiculturalism } \\
\text { freedom } \\
\text { Signified }\end{array}$ \\
\hline & $\begin{array}{l}\text { hip hop } \\
\text { Sign }\end{array}$ & \\
\hline
\end{tabular}

\section{Conclusion}

The discussions can be concluded in this part of study. It can be seen that Barthes' semiotics has guided this study. His myth theory is more meaningful to be analyzed under the umbrella of American Studies approach. It is because knowledge from other studies is required as American Studies theorist Robert Sklar said. Moreover, Leo Marx also suggests that micro work is the representation of the macro universe. His theory allows study on movies as the artifact to generalize American values. Thus, the information from the secondary data is useful in getting deeper analysis.

Understanding on hip hop through American experience has helped this study to reveal the phenomena reflected in movies. Barthes' myth theory leads this comprehension to stages of meaning making on the first and second ordersemiological system. The signifier that can be found in the Save the Last Dance and Step Up movies is hip hop. It is manifested in hip hop related scenes in the seven movies.

The hip hop related scenes seen in youngsters' delinquency and artistic expression portray a sign of rebellion. This portrayal reveals American values of rebellion. However, Barthes' myth theory that emphasizes on knowledge of American experience suggests value of freedom.

American values are also can be seen from the depiction of hip hop related scenes in the audition, showcase, and competition. Through the discussion of dancers' hard life, American values of competitive, hard work and determination are achieved. Thus, understanding in the belief in the land of opportunity and equality in American experience help to reveals American values of optimism and materialism.

\section{Bibliography}

Abid, Sabrina A. The Pursuit of Happiness: The State of the American Dream in Suzan-Lori Parks's Topdog/Underdog. Thesis, Georgia State University. 2012.

Abrahams, Roger D. Cultural Differences and the Melting Pot Ideology. Educational Leadership , 29, 2, 118-21, Nov 1971.

Adaso, Henry. Hip Hop Timeline. PDF form: http://about.com. (accessed on January 2013).

Adi, Ida Rochani. Reconciling the American Myth of Innocence with Popular Consciousness: A Study on American Action Films of 1990s. Yogyakarta: Universitas Gadjah Mada $<$ http://digilib.fib.ugm.ac.id/book /detail/4612>. 2003.

Anderson, Terry H. The Sixties (Fourth Edition). Boston: Pearson. 2012.

Barthes, Roland. Mythologies. New York: The Noonday Press. 1991. 
Baxter, Vern Kenneth and Peter Marina. Cultural Meaning and Hip-Hop Fashion in the African-American Male Youth Subculture of New Orleans. Journal of Youth Studies Vol. 11, No. 2, April 2008, 93-113.

Edgar-Hunt, Robert, et al. Basic Film Making 04: The Language of Film. New York: Ava Publishing. 2010.

Graaf, John de and Laura Musikanski. Land Journal, Autumn 2011, p. 56-59. The Pursuit of Happiness. www.earthislandjournal.org. 2011.

Hart, Walter Edward. The Culture Industry, Hip Hop Music and the White Perspective: How OneDimensional Representation of Hip Hop Music has Influenced White Racial Attitudes. Arlington: University of Texas. 2009.

Hirschman, Charles. America's Melting Pot Reconsidered. Annual Review of Sociology, Volume 9 (1983), 397-423. 1983.

Hoch, Danny. "Introduction". Jails, Hospitals, \& Hip-Hop and Some People. New York: Villard. 1993.

Huber, Jeffrey J. Applying Educational Psychology in Coaching Athletes. Illinois: Human Kinetics. 2013.

Kurian, George T. Encyclopaedia of American Studies. New York: Grolier. 2001.

Lipsitz, George. Dangerous Crossroads: Popular Music, Postmodernism, and the Poetics of Place. London: Verso. 1994.

Matza, David. Juvenile Delinquency and Subterranean Values (with G.
Sykes) American Sociological Review 26: 712-29. 1961.

Montagu, Ashley. The American Way of Life. New York: G.P. Putnam's Sons: 1967.

Motley, Carol $\mathrm{M}$ and Henderson. The global hip-hop Diaspora: Understanding the Culture. Journal of Business Research (Impact Factor: 1.48). 03/2008.

Muhni, Djuhertati Imam. Bunga Rampai dari Amerika: American Bouquet. Yogyakarta: Impulse. 2010.

Mukerji, Chandra and Michael Schudson. Rethinking Popular Culture: Contemporary Perspectives in Cultural Studies. Oxford: University of California Press. 1991.

Muniroh, Zahrotul. The Pursuit of Happiness in F. Scott Fitzgeralds' the Great Gatsby. Thesis, Yogyakarta: Universitas Gadjah Mada. 2009.

Murray, Charles. The Pursuit of Happiness under Socialism and Capitalism. Cato Journal, Vol. 11, No. 2 (Fall 1991), p. 239-258. Cato Institute. 1991.

Nachbar, Jack and Kevin Lause. 1992. Popular Culture: An Introductory Text. Bowling Green State University Popular Press: Bowling Green, Ohio.

Owen, Diana. American Identity, Citizenship, and Multiculturalism. Washington: Georgetown University. 2005.

Perkins, William Eric. Droppin' Science: Critical Essays on Rap Music and Hip Hop Culture. Philadelphia: Temple UP. 1996. 
Price, Emmett G. Hip Hop Culture. California: ABC-CLIO, Inc. 2006.

Putranto, Aji Prasetio. The Pursuit of American Dream in the Main Character of Dreiser's Sister Carrie. Thesis, Yogyakarta: Universitas Gadjah Mada. 2012.

Richardson, J. W., \& Scott, K. A. Rap music and its violent progeny: America's culture of violence in context. Journal of Negro Education, 17, 175-192. 2002.

Schupp, Karen. Studying Dance (A Guide for Campus and Beyond). Arizona State University: Human Kinetics. 2015.

Ulinnuha, Roma. The Statue of Liberty and Ellis Island: Icon and Symbol.
Thesis, Yogyakarta: Universitas Gadjah Mada. 2005.

Valle, Toni. University of Houston School of Theater \& Dance presents Emerging Choreographers Showcase. Texas: University of Huston. 2014.

Watkins, S. Craig. Hip Hop Matters: Politics, Pop Culture, and the Struggle for the Soul of a Movement. Boston: Beacon Press. 2005.

Hip-Hop at the Museum? Heinemann and Carus Publishing. 2007.

(http://americanhistory.si.edu/) (January 2013) 